JETE : VOL 2 NO $12021 *$ E-ISSN : 2745-9888* P-ISSN : 2745-9896

Journal of Education and Teaching

http://ejournal.uin-suska.ac.id/index.php/JETE

\title{
THE INFLUENCE OF STUDENTS' UNDERSTANDING OF SENTENCE PATTERN AND VOCABULARY MASTERY ON THEIR READING COMPREHENSION AT THE FIRST YEAR OF STATE VOCATIONAL SENIOR HIGH SCHOOL 1 LOGAS TANAH DARAT KUANTAN SINGINGI REGENCY
}

\author{
${ }^{1}$ Sepri \\ ${ }^{1}$ Universitas Islam Negeri Sultan Syarif Kasim Riau, Indonesia \\ Email: ${ }^{1}$ ssepri2019@gmail.com
}

Received: 30 Oktober 2019; Accepted 28 Mei 2021; Published 31 Mei 2021

Ed 2021; 2 (1): 8-21

\begin{abstract}
ABSTRAK
Tujuan utama dari penelitian ini adalah untuk mengetahui pengaruh pemahaman pola kalimat dan penguasaan kosakata siswa terhadap pemahaman membaca teks recount di SMK Negeri 1 Logas Tanah Darat Kuantan Singingi. Penelitian ini merupakan penelitian korelasional yang terdiri dari tiga variabel; dua variabel bebas yaitu pemahaman pola kalimat dan penguasaan kosakata siswa, dan satu variabel terikat yaitu pemahaman siswa dalam membaca teks recount. Partisipan penelitian terdiri dari 175 siswa kelas X SMK Negeri. Instrumen yang digunakan untuk mengumpulkan data adalah tes. Setelah menganalisis data yang terkumpul dengan menggunakan SPSS, diperoleh hasil bahwa pemahaman siswa terhadap pola kalimat berada pada level tinggi $(\mathrm{M}=73,30, \mathrm{SD}=1,59)$ dan penguasaan kosakata mereka juga pada level tinggi $(\mathrm{M}=70,97, \mathrm{SD}=1,56)$. Selain itu, pemahaman bacaan mereka terhadap teks recount juga tinggi $(\mathrm{M}=67,91, \mathrm{SD}=1,66)$. Setelah menganalisis data dengan menggunakan regresi berganda, ditemukan adanya pengaruh yang signifikan antara pemahaman siswa tentang pola kalimat dan penguasaan kosakata terhadap pemahaman membaca teks recount, di mana $F=82,14, p=0,000<0,05$. Kemudian persentase pemahaman pola kalimat dan penguasaan kosakata siswa sebesar 0,842 (84,20\%). Dengan demikian hipotesis alternatif diterima dan hipotesis nol ditolak.
\end{abstract}

Kata Kunci: Pengaruh, Pola Kalimat, Penguasaan Kosakata, Pemahaman Membaca

THE INFLUENCE OF STUDENTS' UNDERSTANDING OF SENTENCE PATTERN AND VOCABULARY MASTERY ON THEIR READING COMPREHENSION AT THE FIRST YEAR OF STATE VOCATIONAL SENIOR HIGH SCHOOL 1 LOGAS TANAH DARAT KUANTAN SINGINGI REGENCY 


\begin{abstract}
The main purpose of this research is to find out the influence of students' understanding of sentence pattern and vocabulary mastery on their reading comprehension of recount text at State Vocational Senior High Schoo 1 Logas Tanah Darat Kuantan Singingi Regency. This is a correlational research that consists of three variables; two independent variables, namely the students'understanding of sentence pattern and their vocabulary mastery, and one dependent variable which is the students' reading comprehension of recount text. The research participants consisted of 175 tenth-grade students at the State Vocational Senior High School. The instruments that were used to collect the data are tests. After analysing the collected data by using SPSS, the results showed that the students' understanding of sentence pattern is at the high level $(M=73.30, S D=1.59)$ and their vocabulary mastery is also at the high level $(M=70.97, S D=1.56)$. Besides, their reading comprehension of recount text is at the high level too $(M=67.91, S D=1.66)$. After analysing the data by using multiple regressions, the finding indicated that there is a significant influence of the students' understanding of sentence pattern and vocabulary mastery on their reading comprehension of recount text, in which $F=82.14, p=0.000<0.05$. Then the percentage of the students' understanding of sentence pattern and vocabulary mastery is 0.842 (84.20\%). Therefore, the alternative hypothesis is accepted and the null hypothesis is rejected.
\end{abstract}

Keywords: Influence, Sentence Pattern, Vocabulary Mastery, Reading Comprehension

\title{
INTRODUCTION
}

Reading is an important element in learning. In other words, reading ability plays an essential role in language acquisition. In many parts of the world, reading knowledge of a foreign language is usually significant to academic studies, professional success and personal development. As what Brown (2004:185) states that reading is the most essential skill for success in all educational contexts. It means that reading is an important part of the four necessary language skills for academic success. Furthermore, students will not master English well without good reading ability.

Because of its importance, the teaching of English in the national curriculum is targeted to graduate students who reach certain levels of literacy in which they are expected to be able to read various kinds of genre. According to the national curriculum based on Depdiknas, SK and KD Bahasa Inggris SMA/MA, (2016), the scope of English subjects in Senior High Schools includes the ability to understand a variety of functional text, monologues and short-essay in form of procedure, descriptive, recount, narrative, report, news item, analytical exposition, hortatory exposition, spoof, explanation, discussion, reviews, and public speaking.

Based on the curriculum, the first year students of State Vocational Senior High School 1 Logas Tanah Darat are expected to understand recount texts, not only about the factual information, main idea, meaning of difficult words, reference and inference of the texts, but they also understand about the generic structure of the texts. However, many students had difficulties in comprehending recount text. They could not identify the main idea of the text. They had difficulties in understanding reference and generic structure of the text. They also had lack of vocabulary. 
According to the English curriculum for senior high schools in Indonesia, the English teaching covers four skills, namely reading, listening, speaking, and writing. The four skills are supported by learning of language elements. The language components involve vocabulary, grammar, and pronunciation. In fact of all language components, vocabulary holds the main core in language teaching. This is in line with what Richards and Renandya (2002:255) say that vocabulary is a core component of language proficiency and provides much of the basis for how well learners speak, listen, read, and write. It means that to improve their language skills, learners must master vocabulary.

Another essential of vocabulary mastery is it can make learners efficiently communicate and fundamentally comprehend on English articles and academic essays (Dickinson, 1987). The two aspects are really newsworthy. Lots of people are well known all over the word because of their abundance knowledge which is supported by their capability in communicating in English well. Besides, lots of newsworthy knowledge and references can be taken from English articles and academic essays.

Further, according to National Institute of Child Health and Human Development (NICHD,2000) Vocabulary knowledge is essential to comprehend the text. When students do not understand at least $90 \%$ of the words in a text, they do not adequately understand what they read (Hirsch, 2003; Sedita, 2005). Hirsch suggests that students acquire 2,000 to 3,500 new words a year and know the meaning of approximately 50,000 words by the time they graduate from high school (Graves, 2006; Lehr, Osborn, and Hiebert, 2004; PREL, 2008).

In reading, for instance, the students will get difficulties in comprehending a text if they do not know the meaning of words in the text. In relation to the objective of teaching reading in senior high schools, which provides the students with the abilities to get the information from books which are written in English. The students' difficulties in reading influence their learning achievements. Most of the tests for assessing students' learning achievements contain reading comprehension questions. As the result, most of the students did not reach the minimum criteria of achievement. Recently, the English teacher of State Vocational Senior High School 1 Logas Tanah Darat showed a result of his students' unit review for recount text to the researcher. The result showed that only eight $(22.85 \%)$ students who could reach the minimum criteria of achievement which is 78 . Thus, $77.14 \%$ of the students should follow remedial class.

Many factors can influence students' reading comprehension. Being an educator, the researcher is interested in studying the factors influencing the reading ability of students at senior high school so as to develop suitable means to help boost their reading comprehension of recount text. As a preliminary investigation, the researcher found: 1.Not all students understand the basic components of a sentence (subject, verb, and object). 2.They often are not familiar with the vocabulary they encounter, and have trouble determining word meanings. 3. Some students do not have knowledge about sentences patterns (simple sentence, compound sentence, complex sentence, and compound-complex sentence).4. Some of the students do not have knowledge about the language features of recount text, although they had learned it in grade VIII at junior high school and 5. All students are expected to understand recount texts, but not all students can read recount text with good comprehension. 
Those preliminary findings are the problems that faced by the first year students of State Vocational Senior High School 1 Logas Tanah Darat, Kuantan Singingi Regency. The problems impede the students' reading comprehension of recount text. Consequently, the students do not reach the expected achievement that stated in the national curriculum.

To solve the problem, students need to improve their understanding of sentence pattern and their vocabulary mastery. It is because every paragraph in recount text is made up of sentences which use simple past tense (had, visited), specific subject (Mr. John, I, we), action verb (helped, crutched), object, and adverb phrase to indicate when and where (yesterday, after lunch, in the shed, at home, outside) (Doddy, Sugeng and Effendy, 2008:14). So, in order to read the recount text with comprehension, the students should be able to understand the pattern of those sentences. This idea is in line with McWorther (1986:16), who argues that understanding sentence pattern can influence comprehension. In short, to understand the whole text, the students should have knowledge of sentence patterns. Thus, it is necessary for the students to have reading ability in understanding sentences pattern in order to read with good comprehension. another important factor in comprhending a text is vocabulary. vocabulary is an important factor in the comprehension of language and the number of words acquired by a learner is related to competent language use (Nation, 1990). Students who have a limited vocabulary are at risk of not becoming proficient in reading (Beck and McKeown, 2005; Blachowicz and Fisher, 2000. In addition, vocabulary is a major factor of poor reading comprehension, and students' word knowledge is strongly linked to success in academics (NRP, 2000 and Nagy, 1998). Stahl and Nagy (2006) add that the more words we have, the more complex ways we can think about the world.

In conclusion, to enhance students' reading comprehension of recount text, it is important to investigate the students' understanding of sentence pattern and their voacabullary mastery as part of the factors that may influence their reading comprehension. For that reason, researcher strives to study the influence of understanding sentence and vocabulary as factors that influence the reading ability of the first year students in reading recount text at State Vocational Senior High School 1 Logas Tanah Darat. Therefore, this research is proposed to explain scientifically whether students' understanding of sentence pattern and their vocabulary influence their reading comprehension. To do that, this research entitled "The Influence of Students' Understanding of Sentence Pattern and Vocabulary Mastery on Their Reading Comprehension at The First Year of State Vocational Senior High School 1 Logas Tanah Darat Kuantan Singingi Regency".

\section{METODOLOGY}

The primary purpose of this research is to find out the influence of understanding sentence pattern and vocabulary mastery upon reading comprehension of recount text. Thus, the appropriate research design for this research is a correlational research which analyzes the data by using statistical regression. According to Gay and Airisian (2000:311), a correlational research involves collecting data to determine whether, and to what degree, a relationship exists between two or more quantifiable variables. Like statistical correlations (product moment correlation coefficient), statistical regression examines the association or relationship between variables (Geoffrey Marczyk et al, 2005:239). 
However, the main purpose of statistical regression is prediction or finding the percentage of influence.There are three variables used in this research, firstly independent variable students' understanding of sentence pattern that was symbolized by " $\mathrm{X}$ " and students' mastery of vocabulary which is symbolized by " $\mathrm{X}^{2}$ ", and dependent variable is students' reading comprehension symbolized by "Y". The researcher believes that this research design is able to look at three variables and determine if a relationship exists between those variables.

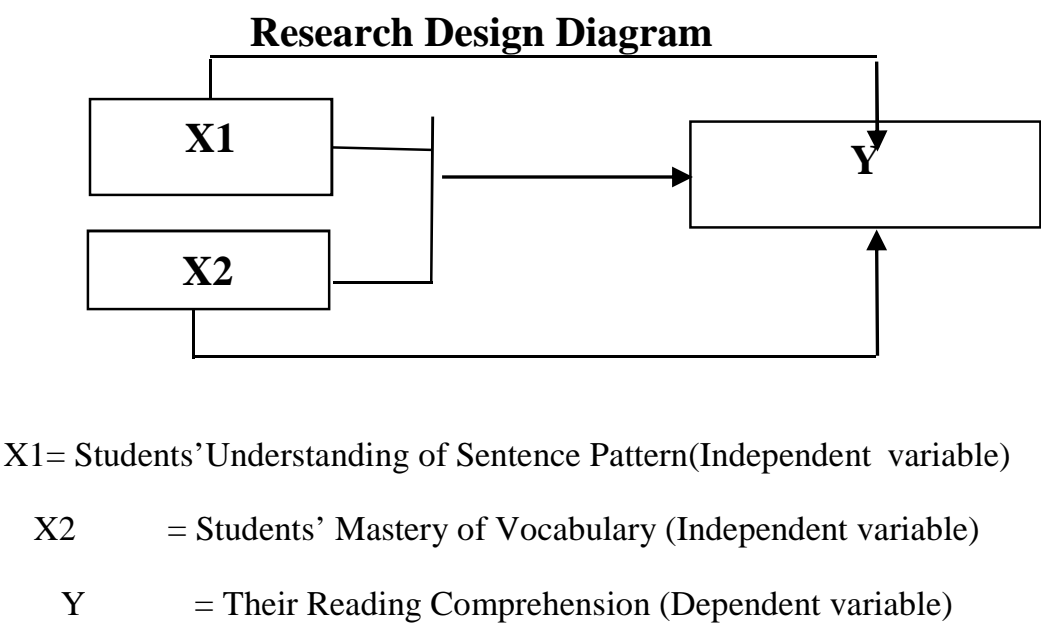

(Hatch and Farhady, 1982:27)

This research will be conducted at State Vocational Senior High School 1 Logas Tanah Darat. It will be conducted in the first semester of 2019/2020 academic year. It will be conducted in October to November 2019. The first year students of State Vocational Senior High School 1 Logas Tanah Darat participated as the subject of this research. And, the object of this research is the influence of understanding sentence pattern and vocabulary mastery on reading comprehension. The first year students of State Vocational Senior High School 1 Logas Tanah Darat referred to the population of this research. The sampling technique that used in this research is total sampling where all students in the population will be referred as the research sample. Gay and Airisian (2000:332) state that for a correlational research, "30 participants are generally considered to be a minimally acceptable sample size". Thus, the researcher will take all students in population as research sample. The following table shows the description of population and sample of this research.

\begin{tabular}{|c|c|c|c|c|c|}
\multicolumn{9}{c|}{ Research Sample } \\
\cline { 2 - 5 } \multirow{2}{*}{ No } & \multirow{2}{*}{ Students Group } & Male & Female & Total & \multirow{2}{*}{ Sample (100\%) } \\
\hline 1 & Class A & 15 & 19 & 34 & 34 \\
\hline 2 & Class B & 16 & 19 & 35 & 35 \\
\hline 3 & Class C & 15 & 20 & 35 & 35 \\
\hline 4 & Class D & 20 & 16 & 36 & 36 \\
\hline 5 & Class E & 21 & 14 & 35 & 35 \\
\hline \multicolumn{2}{|c|}{ Total } & 87 & 88 & 175 & 175 \\
\hline
\end{tabular}


The researcher will use test of understanding sentence pattern and test of vocabulary mastery and test of reading comprehension of recount text as the technique of collecting the research data. Tests of understanding sentence pattern and vocabulary mastery will be used to find out the first year students' ability in understanding sentence pattern and mastering vocabulary at State Vocational Senior High School 1 Logas Tanah Darat. Then, reading comprehension test of recount text will be used to find out the first year students' reading comprehension of recount texts at State Vocational Senior High School 1 Logas Tanah Darat by giving them some recount texts with comprehension questions. All data that gained through test will be analyzed to find out the significant influence of understanding sentence pattern and vocabulary mastery on reading comprehension of recount text at the first year students of State Vocational Senior High School 1 Logas Tanah Darat.

According to Gay (2000:161), explained that validity is concerned with the appropriateness of the interpretation made from test scores. Furthermore, Gay (2000:169) stated that a good instrument must have two essential requirements: validity and reliability. Reliability is the degree to which a test consistently measures whatever it is measuring. Therefore, both tests should have validity and reliability. The followings were the procedures of validity and reliability testing of this research. Heaton (1995:159) states that the validity of a test is "the extent to which it measures what it is supposed to measure and nothing else". The Understanding of Sentence Pattern Test consist of 25 items was tried out to 34 students. The validity of the test wasa analyzed by using SPSS 24.0 program version. The items are valid if $r_{\text {obtained }}$ is smaller than $\alpha\left(\mathrm{r}_{\text {obtained }}<0.05\right)$. The test result shows that $\mathrm{r}$ obtained of each item of the test is smaller than $\alpha=0.05$ which means that the 25 items are valid.. The Vocabulary Mastery Test consist of 20 items was tried out to 34 students.. Test result shows that $r_{\text {obtained }}$ of each item of the test is smaller than $\alpha=0.05$ which means that the 20 items are valid.. The Reading Comprehension Test consist of 25 items was tried out to 34 students. Test result shows that $r_{\text {obtained }}$ of each item of the test is smaller than $\alpha=$ 0.05 which means that the 25 items are valid. Thus, these 3 variables is this research Tests could be used to measure students' understanding of sentence pattern, vocabulary mastery and reading comprehension of recount text and collected data for the research.

Next to fix the instruments, the researcher also conducted reliability test. Realibility refers to whether a test measure something well (Miles \& Banyard, 2007:270). To test the instrument reliability, there are 2 ways to calculate these, the first manually calculation by using Hoyt's formula. Arikunto (2010:191-195) and the second is by using SPSS program. In this research was used the second way, and the result as follows: The test of understanding of sentence pattern shows the value of Cronbach Alpha is 0.860 which indicate the reliability of the understanding of sentence pattern test distributed to the students are highly reliable because the value is in the range of $0.80-0.90$ which means the test is reliable and acceptable to be used as the instrument of the data collection. then test of vocabulary mastery shows the value of Cronbach Alpha is 0.793 which indicate the reliability of the vocabulary mastery test distributed to the students are reliable because the value is in the range of $0.70-0.79$ which means the test is reliable and acceptable to be used as the instrument of the data collection. And the last the reliability test of reading comprehension shows the value of Cronbach Alpha is 0.854 which indicate the reliability of the reading comprehension test distributed to the students are highly reliable because the 
value is in the range of $0.80-0.90$ which means the test is reliable and acceptable to be used.

The Level of Reliability

\begin{tabular}{|c|c|c|}
\hline No & Reliability & Level of Reliability \\
\hline 1 & $>0.90$ & Very Highly Reliable \\
\hline 2 & $0.80-0.90$ & Highly Reliable \\
\hline 3 & $0.70-0.79$ & Reliable \\
\hline 4 & $0.60-0.69$ & Minimally Reliable \\
\hline 5 & $<0.60$ & Unacceptably Low Reliability \\
\hline
\end{tabular}

In order to test each hypothesis in analyzing the data which is going to find out the influence of understanding sentence pattern (variable $\mathrm{X}^{1}$ ) and mastery of vocabulary $\left(\mathrm{X}^{2}\right)$ on reading comprehension (variable $\mathrm{Y}$ ), the researcher will use simple regression analysis. It can be done by following the steps that suggested by Riduwan (2009:228-229) and also can be done by using SPSS Program. The Formula Multiple Regression will be used to test the third hypothesis using SPSS version 24.0.

\section{RESULTS AND DISCUSSION}

In this section, the outcomes or results of the data analysis as the answer of the research questions were presented according to the sequence of the research questions. The findings were the outcomes of examining of (1) the influence of understanding of sentence pattern on reading comprehension, (2) the influence of vocabulary mastery on reading comprehension, (3) the influence of understanding of sentence pattern and vocabulary mastery on reading comprehension.

Is there any significant influence of students' understanding of sentence pattern on their reading comprehension in grade $X$ of State Vocational Senior High School 1 Logas Tanah Darat?

Model Summary of Students' Understanding of Sentence pattern on Their Reading Comprehension of Recount text

\begin{tabular}{|l|r|r|r|r|r|}
\hline \multicolumn{7}{|c|}{ Model Summary $^{\mathbf{b}}$} \\
\hline Model & $\mathrm{R}$ & R Square & $\begin{array}{c}\text { Adjusted R } \\
\text { Square }\end{array}$ & $\begin{array}{c}\text { Std. Error of } \\
\text { the Estimate }\end{array}$ & $\begin{array}{c}\text { Durbin- } \\
\text { Watson }\end{array}$ \\
\hline 1 & $.582^{\mathrm{a}}$ & .670 & .610 & 16.109 & 1.804 \\
\hline a. Predictors: (Constant), understanding of sentence pattern \\
\hline b. Dependent Variable: reading comprehension \\
\hline
\end{tabular}

The table above shows $\mathrm{R}$ is 0.582 which is the square of the correlation coefficient $(0.250 \times 0.250=0.063)$. Standard Error of the Estimate is 16.11 , note the descriptive analysis statistically that the value which is much smaller than the standard error. By orienting number of significance, If probability $>0.05$, null hypothesis $(\mathrm{H} 0)$ is rejected. If probability $<0.05$ alternative hypothesis $(\mathrm{Ha})$ is accepted. So, by looking at the value of 
Sig. (2-tailed) that is $<$ than $\alpha$ (the significant level) it can be said that there is a Significant Influence of students' understanding of sentence pattern on students' reading comprehension of recount text because of the value of sig. (2-tailed) is $0.000<0.05$, and also the value of regression, by comparing it at significant level $5 \%$ or $12.386>0.001$. This kind of regression includes positive influence. It means that when students have good understanding of sentence pattern then followed by going up of students' reading comprehension of recount text or on the contrary when students have bad understanding of sentence pattern then followed by going down of the students' reading comprehension of recount text. Then, by looking at the value of regression, it can be interpreted that correlation between students' understanding of sentence pattern and students' reading comprehension of recount text is enough correlation.

In conclusion, hypothesis alternative (Ha1) is accepted. So, there is an influence of students' understanding of sentence pattern on students' reading comprehension of recount text of the first level of SMKN 1 Logas Tanah Darat.

\section{Is there any significant influence of students' vocabulary mastery on their reading comprehension in grade X of State Vocational Senior High School 1 Logas Tanah Darat?}

Model Summary of Students' Vocabulary Mastery on Their Reading Comprehension of Recount text

\begin{tabular}{|l|r|r|r|r|r|}
\hline \multicolumn{7}{|c|}{ Model Summary $^{\mathbf{b}}$} \\
\hline Model & $\mathrm{R}$ & $\mathrm{R}$ Square & $\begin{array}{c}\text { Adjusted R } \\
\text { Square }\end{array}$ & $\begin{array}{l}\text { Std. Error of } \\
\text { the Estimate }\end{array}$ & $\begin{array}{c}\text { Durbin- } \\
\text { Watson }\end{array}$ \\
\hline 1 & $.723^{\mathrm{a}}$ & .540 & .520 & 6.258 & 1.764 \\
\hline
\end{tabular}

In the table above shows $\mathrm{R}$ is 0.723 and $\mathrm{R}$ Square is $=0.540$ ). Standard Error of the Estimate is 6.29 , note the descriptive analysis for statistically that the value which is much smaller than the standard error. By looking at the value of Sig. (2-tailed) that is $<$ than $\alpha$ (the significant level) it can be said that there is a significant influence of students' vocabulary mastery on reading comprehension of recount text because of the value of sig. (2-tailed) is $0.003<0.05$, it can be said that there is a significant influence between students' vocabulary mastery and reading comprehension of recount text, and also the value of Regression, it is higher than $t_{\text {table }}$ by comparing it at significant level $5 \%$ or $9.013>$ 0.003. This kind of Regression includes positive influence. It means that when students have high vocabulary mastery then followed by going up of students' reading comprehension of recount text or on the contrary when students have low vocabulary mastery then followed by going down of the students' reading comprehension. Then, by looking at the value of Regression, it can be interpreted that correlation between students' vocabulary mastery and reading comprehension of recount text is enough correlation. 
In conclusion, hypothesis alternative (Ha2) is accepted. So, there is an influence of students' vocabulary mastery on students' reading comprehension of recount text of the first level of SMKN 1 Logas Tanah Darat.

Is there any influence of students' understanding of sentence pattern and vocabulary on their reading comprehension of recount text in grade $X$ of State Vocational SeniorHigh School 1 Logas Tanah Darat? The third research question can be proved by statistical analysis using multiple regression. It is explained on the tables below: Model Summary of Students' Understanding of Sentence pattern and Vocabulary on Their Reading Comprehension of Recount text

\begin{tabular}{|c|c|c|c|c|}
\hline \multicolumn{5}{|c|}{ Model Summary ${ }^{\mathbf{b}}$} \\
\hline Model & $\mathrm{R}$ & R Square & $\begin{array}{l}\text { Adjusted R } \\
\text { Square }\end{array}$ & $\begin{array}{l}\text { Std. Error of the } \\
\text { Estimate }\end{array}$ \\
\hline 1 & $.842^{\mathrm{a}}$ & .785 & .760 & 15.985 \\
\hline \multicolumn{5}{|c|}{$\begin{array}{c}\text { a. Predictors: (Constant), vocabulary mastery, understanding of } \\
\text { sentence pattern }\end{array}$} \\
\hline \multicolumn{5}{|c|}{ b. Dependent Variable: reading comprehension } \\
\hline
\end{tabular}

The table above explains the percentage of the influence of students' understanding of sentence pattern and students' vocabulary mastery on their reading comprehension of recount text. The value of $r$ Square is 0.785 , it means that the influence of students' understanding of sentence pattern and students' vocabulary mastery on their reading comprehension of recount text is $78.5 \%$. And an adjusted $r$ square of 0.760 , this means that students' understanding of sentence pattern and students' vocabulary mastery combined together to significantly influence the students' reading comprehension of recount text. To determine whether there is significant influence or not of students' understanding of sentence pattern and students' vocabulary mastery on students' reading comprehension of recount text, it can be seen from tables below

\section{Analysis of Variance of Students' Understanding of Sentence pattern and Vocabulary on Their Reading Comprehension of Recount text}

\begin{tabular}{|c|c|c|c|c|c|c|}
\hline \multicolumn{7}{|c|}{ ANOVA $^{b}$} \\
\hline \multicolumn{2}{|c|}{ Model } & $\begin{array}{l}\text { Sum of } \\
\text { Squares }\end{array}$ & Df & Mean Square & F & Sig. \\
\hline \multirow[t]{3}{*}{1} & Regression & 4160.081 & 2 & 2080.040 & 82.140 & $.000^{\mathrm{a}}$ \\
\hline & Residual & 43949.633 & 172 & 255.521 & & \\
\hline & Total & 48109.714 & 174 & & & \\
\hline \multicolumn{7}{|c|}{ a. Predictors: (Constant), vocabulary mastery, understanding of sentence pattern } \\
\hline \multicolumn{7}{|c|}{ b. Dependent Variable: reading comprehension } \\
\hline
\end{tabular}


Table above explains whether there is an influence or not of students' understanding of sentence pattern and vocabulary on their reading comprehension of recount text, the score of "sig" in the table above indicates the significant influence of students' understanding of sentence pattern and mastery of vocabulary on students' reading comprehension of recount text. Based on the table above, it can be seen from score of "sig is lower than 0.05, sig. $0.000<0.05$ so, it means that there is a significant influence of students' understanding of sentence pattern and vocabulary on their reading comprehension of recount text. The table above also shows that the analysis of variance for multiple regression data produced an $\mathrm{F}$ ratio of 82.140 . this indicates that the effectiveness of the independent variables in predicting the students' reading comprehension of recount text could not have been due to chance. Then, it can be concluded that the two factors are relevant in predicting and improving students' reading comprehension of recount text.

\section{Coofficient Correlation of Students' Understanding of Sentence pattern and Vocabulary on Their Reading Comprehension of Recount text}

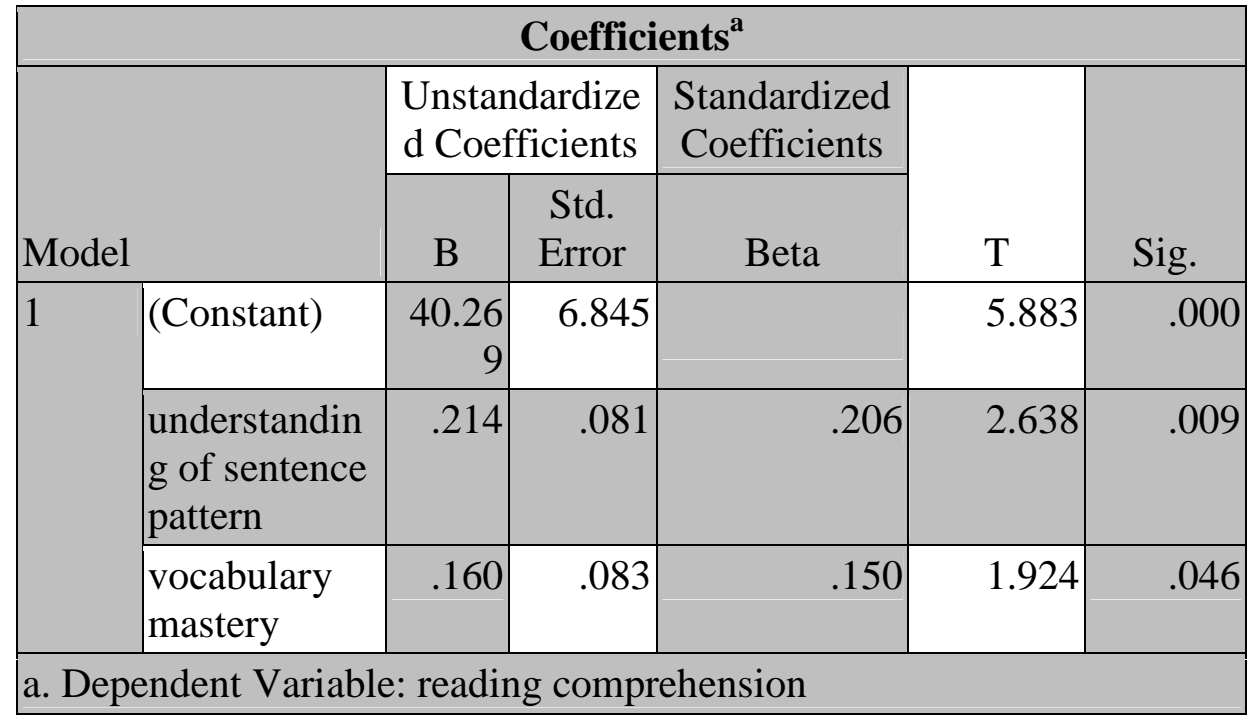

Based on the above table, it can be seen that the value of B Constant is 40.269 and the value of $\mathrm{T}$ for Constant is 5.883, and the significant level of 0.05 was obtained 0.000 . It also can be seen that the value of $\mathrm{B}$ for $\mathrm{X} 1$ is 0.214 , and the value of $\mathrm{T}$ is 2.638 and the significant level of 0.05 is obtained 0.009 . It also can be seen that the value of $\mathrm{B}$ for $\mathrm{X} 2$ is 0.160 , and the value of $\mathrm{T}$ is 1.924 and the significant level of 0.05 is obtained 0.046 , because $\mathrm{T}$ arithmetic> Sig then Ho is rejected. whereas sig in Table B is 0,000, which means the probability 0,000 , because the probability is less than 0.05 , then rejected.

In conclusion, hypothesis alternative (Ha3) is accepted. So, there is an influence of students' understanding of sentence pattern and vocabulary on their reading comprehension of recount text of the first level of SMKN 1 Logas Tanah Darat. It can be proved by mean score of students' understanding of sentence pattern and vocabulary on their reading comprehension of recount text. The mean score of students' understanding of sentence pattern and vocabulary was $(73.30+70.97: 2=72.14)$ and the mean score of students' reading 
comprehension of recount text is 67.31. It means that, both of the mean score of students' understanding of sentence pattern and vocabulary mastery, students' reading comprehension of recount text can be categorized into high level, so if the students have positive and high understanding of sentence pattern and vocabulary mastery, they will have high reading comprehension of recount text.

\section{DISCUSSION}

In this study the major research question is; "Is there significant influence of student's understanding of sentence pattern and vocabulary on their reading comprehension of recount text at the first grade of SMKN 1 Logas Tanah Darat?". And then, there are three Hypothesis in this research, the first is Ha: showing the influence of student's understanding of sentence pattern on their reading comprehension of recount text, the second is Ha showing the influence of students' vocabulary mastery on students' reading comprehension of recount text, the last is Ha showing the influence of students' understanding of sentence pattern and vocabulary mastery on their reading comprehension of recount text. Based on the main research question above, it can be divided into some minors' research questions. These research questions stated as follow: 1) Is there any significant influence of students' understanding of sentence pattern on their reading comprehension of recount text in grade X of State Vocational Senior High School 1 Logas Tanah Darat?; 2) Is there any significant influence of students' vocabulary mastery on their reading comprehension of recount text in grade X of State Vocational Senior High School 1 Logas Tanah Darat?; 3) Is there any significant influence of students' understanding of sentence pattern and vocabulary on their reading comprehension of recount text in grade $\mathrm{X}$ of State Vocational Senior High School 1 Logas Tanah Darat?

In order to answer objectives of the research about the influence of students' understanding of sentence pattern on their reading comprehension of recount text, Simple Regression analysis was conducted. As the finding of this study showed that there was significant influence of students 'understanding of sentence pattern on students' reading comprehension of recount text. It can be known from the score of sig. $<0.05$. Score of "sig." is 0.000. It also can be seen from the mean score of students' understanding of sentence pattern was 73.30 and the mean score of students' reading comprehension of recount text was 67.31. It meant that if the students had high understanding of sentence pattern, they would have high reading comprehension of recount text. This finding supported by the result of research conducted by Ririnkholidiana (2018: 86). She found that there was a significant correlation between grammar mastery and reading comprehension with the coefficient correlation was .475 .

Then, to know about the influence of students' vocabulary mastery on students' reading comprehension of recount text, the simple regression analysis was also used. The value of Sig. (2-tailed) is 0.000 . It also can be seen from students vocabulary mastery mean score (70.97) and students' reading comprehension of recount text was (67.31), it indicated that if students had high mastery of vocabulary, they would have a high reading comprehension. The similar result from Saeed (2015: 667) she found that vocabulary 
mastery and reading comprehension have mutual influence on each other, and research shows that vocabulary mastery have more and better reading comprehension. This finding is in line with the findings of other studies in which vocabulary mastery had relation to reading comprehension (Ai, 1999; Atkinson, 2004; Fortner, 1986). This finding also support the idea of Bano et al (2014: 604) who state that reading comprehension and vocabulary mastery are not only positively related to each other but are also highly correlated.

Lastly, to find out about the influence of students' understanding of sentence pattern and vocabulary mastery on their reading comprehension of recount text the multiple regression analysis was also used. As the result of the study, the value of Sig. (2-tailed) < 0.05 , the Sig. is 0.000 . It also can be seen from the total of mean score of students' understanding of sentence pattern and vocabulary mastery $(73.30+70.97: 2=72.14)$ and the mean score of students' reading comprehension of recount text is 67.31. It is proved that, if students have high understanding of sentence pattern and vocabulary mastery, their reading comprehension also will be high. This finding in line with Murcia (2001) states that grammar and vocabulary have been viewed as completing elements in language teaching. It shows us that grammar especially sentence pattern has a close relationship with vocabulary mastery. Both of them can be combined as the factors that influence reading comprehension.

\section{CONCLUSION}

Thus, based on the result, finding, it can be concluded that at the first grade of State Vocational Senior High School 1 Logas Tanah Darat. the higher students' understanding of sentence pattern, the higher score of students' reading comprehension would be, while the lower of students' understanding of sentence pattern, the lower of the students' reading comprehension would be. Then, the students' reading comprehension was also influenced by students' vocabulary mastery. The higher the students' vocabulary mastery the higher the students' reading comprehension, while the lower the students' vocabulary mastery of the lower of students' reading comprehension. So, in other words, both students' understanding of sentence pattern and vocabulary mastery were positively affected students' reading comprehension. In order to prove the influence of students' understanding of sentence pattern on their their reading comprehension of recount text and the influence of the students' mastery of vocabulary on their reading comprehension of recount text, simple regression is used. Then, multiple regression was used to determine the influence of students' understanding of sentence pattern and vocabulary mastery on their reading comprehension of recount text. the result found that the influence of both independents variable is significant on the dependent variable. Therefore, to improve the students reading comprehension it should be done by improving students' understanding of sentence pattern as wall as their vocabulary mastery too.

\section{REFERENCES}

Achmad Doddy, Ahmad Sugeng, and Effendi. 2008. Developing English Competencies 1: for Senior High School (SMA/MA) Grade X. Jakarta: Pusat Perbukuan, Departemen Pendidikan Nasional. 
Anker. 2010. Real Writing with Readings. Boston: Bedford.

Antony Lewis. 2006. Word Web. Princeton: Princeton University.

AS Hornby, Oxford Advanced Learners Dictionary of Current English, (New York: Oxford University Press, 1990)

Blachowicz and Fisher. 2000. Teaching Discipline-Specific Literacies in Grades 6-12. New Jersey: Pearson Education Ltd.

Brown, H. Doughlas. 2004. Language Assessment: Principles and Classroom Practices. New York: Longman.

Depdiknas. 2006. SK dan KD Bahasa Inggris SD/MI. Jakarta: Puskur, Balitbang Diknas.

Depdiknas. 2006. SK dan KD Bahasa Inggris SMP/MTs. Jakarta: Puskur, Balitbang Diknas.

Depdiknas. 2006. SK dan KD Bahasa Inggris SMA/MA. Jakarta: Puskur, Balitbang Diknas.

Educational Testing Service (ETS). 2005. TOEFL Tips: How to Prepare for the Next Generation TOEFL Test and Communicate with Confidence. Princeton: Educational Testing Service.

Fadilah, Ustadza. 2008. English Sentence Types of Reading Text Book for Junior High School Grade VII. Unpublished Thesis. Malang: State Islamic University of Malang.

Fromkin et al. 2003. Introduction to Language. New York: Thomson Wadsworth.

Geoffrey Marczyk, David DeMatteo, and David Festinger. 2005. Essentials of Research Design and Methodology. New Jersey: John Wiley \& Sons, Inc.

Guthrie, John T., Wigfield, Allan, and Perencevich, Kathleen C. 2004. Motivating Reading Comprehension: Concept-OrientedReading Instruction. New Jersey: Lawrence Erlbaum Associates, Inc.

Heaton, J.B. 1995. Writing English Language Tests. New York: Longman.

Joko Priyana, Riandi, Anita Prasetyo Mumpuni. 2008. INTERLANGUAGE: English for Senior High School Students X: SMA/MA Kelas X. Jakarta: Pusat Perbukuan, Departemen Pendidikan Nasional 
Leung Po Yee, Polly. 2005. The Contribution of Working Memory and Vocabulary Knowledge to English Reading Comprehension in Cantonese-speaking Children. Unpublished thesis for the Degree of Master of Arts, Hong Kong: The University of Hong Kong.

L.R. Gay and Peter Airisian. 2000. Educational Research: Competencies for Analysis and Application. New Jersey: Pearson Education Ltd.

McWorther, Kathleen T. 1986. Guide to College Reading. Boston, Toronto: Little, Brown and Company.

Miles V Zintz. 1975. The Reading Process: The Teacher and Learner. 2nd Edition. Dubuque, Iowa: WM. C. Brown Company Publishers.

Murcia, C. M. 2001. Teaching English as a second or foreign language. Boston: Henley Thompson Learning.

Neil Anderson. 2003. Reading. In D. Nunan (ed.), Practical English Language Teaching. New York: McGraw-Hill.

Purwata, Ichwan. 2008. A Syntactical Analysis on Sentence Patterns used in Westlife's Song Lyrics, Unpublished Thesis. Malang: Universitas Islam Negeri Malang.

Rick Ostrov. 2003. Power Reading. San Francisco: Education Press.

Riduwan. 2009. Dasar-dasar Statistika. Cetakan Ketujuh. Bandung: Alfabeta.

Sandra C. Halverson. 2009. Reading Comprehension in the Classroom. Unpublished thesis for the Degree of Master of Arts in Teaching, Sierra Nevada: Sierra Nevada College.

Suharsimi Arikunto. 2006. Prosedur Penelitian: Suatu Pendekatan Praktik, (Jakarta: Rineka Cipta.

Zainil. 2008. Teacher's Guide for Advanced Students (Intensive and Extensive Reading). Padang: Sukabina Offset.

Zaki, Irwan. 2010. The Structure of Sentence used in Headlines of FourFourTwo Magazine Website. Unpublished Thesis. Malang: Universitas Islam Negeri Malang. 